\title{
Nechkin O.S. \\ Energy-saving panels as modern technologies and materials used in low-rise construction of energy-efficient houses
}

Ural Plant of Energy Saving Panels (UPESP)

(Russia, Yekaterinburg)

doi 10.18411/gq-31-03-2021-24

idsp sciencerussia-31-03-2021-24

The formation of the affordable housing market is one of the priority tasks of the socio-economic development of the country and individual regions, and the possibility of introducing energy-efficient (heat-passive) autonomous houses in the future will be significant when choosing a producer of building materials and a developer in the segment of individual housing construction.

At the same time, the existing technologies for the construction of buildings and structures made of brick, profiled timber, monolith, wood-frame and particleboard construction, have got not only advantages in the form of short deadlines and the ability to erect structures of almost any form, but also serious drawbacks: the complexity, the possible presence of natural radioactivity, the long period of wood drying, grief, the high cost of construction and associated costs, etc.

To date, there is a known method of erecting a monolithic-frame building from multilayer panels with decorative exterior decoration (patent for invention No. RU2515491, dated December 4, 2012), including the formation of a foundation with reinforcing tabs and stops, walls of the first floor with vertical installation of multi-layer panels having voids for pouring concrete, a decorative layer to the outside and vertical openings for the windows between them, the building frame, ceilings and the construction of subsequent floors, and for the formation of walls multilayer panels with a hardened layer located between the decorative and heat-insulating layers, in which the voids for concrete pouring are made in the form of vertical channels located in the heat-insulating layer, while the building frame is formed by pouring vertical channels with reinforcement located in them.

There is a method of building energy-efficient, environmentally friendly structures from prefabricated structures in the form of modular elements (patent for invention No. RU2582241, dated 16.06.2014), by which the structures are mounted on the base, constructed from prefabricated panels of wall structures, floors, coatings and fastened between them, and modular prefabricated elements are made of light steel components and sheathed with sheet material, while the frame of the structure of light steel components is made of a C-profile, and on each mode flax collecting element sheet material fixed on both sides, with symmetrical outwardly shifted by not more than $1 / 2$ the width of the C-profile.

As a prototype of the construction of the building (patent for utility model No. RU80486, dated June 16, 2008), a method is known when a foundation is erected on a selected and marked area using screw piles, exposing them at the same level. Then, to create a single foundation, all screw piles are connected together by a strapping, metal, concrete beam. The base is mounted on the erected foundation, collecting it from three layers, while the base panel is fixed directly to the foundation. After that, walls are erected, the panels of which are connected to the base panels. Beams are installed inside the walls, connecting them together with a connecting element and fasteners. The voids between ordinary beams are filled with insulation, and the corner of the wall where the beam and wall panels are placed is connected with an end connecting element. To give a certain rigidity to the building, the lower and upper ends of the assembled walls are connected with a strapping beam and a ceiling is mounted, also made from standardized panels, laying them on the assembled walls. After that, the elements of the roof and roof are erected.

The disadvantage of the presented prototypes is the ambiguity and complexity of the assembly, the possibility of forming cold bridges during installation, the inability to classify a number of presented prototypes as capital construction and reduced heat transfer resistance, the presence of significant limitations in interior and exterior decoration (the impossibility of 
using modern materials when connecting facade systems and internal cladding) high construction costs and associated construction costs.

The use of energy-saving panels ${ }^{\circledR}$ (hereinafter referred to as ESP) for the purpose of constructing heat-efficient structures can be a high-quality alternative way to construct an energy-efficient facility. Useful product relates to the field of construction of basic and enclosing structures of buildings, and can be used for low-cost and environmentally friendly construction of energy-efficient low-rise buildings with high load-bearing capacity. The technical result when using energy-saving panels is to simplify the construction of low-rise buildings providing high heat transfer resistance allowing the construction of facilities in cold regions of Russia and a significant reduction in heat costs during operation of the facility (energy passivity).

Heat transfer resistance test results are presented in Table 1.

Table 1

Heat transfer resistance test results

\begin{tabular}{|c|c|c|c|}
\hline \multirow{2}{*}{ Controlled parameter } & Test procedure & $\begin{array}{c}\text { Compliance criterion } \\
\text { (normative value) }\end{array}$ & Test results \\
\hline \multirow{2}{*}{ - ESP 160 } & \multirow{2}{*}{ GOST R 56623-2015 } & no less than 3, 73 & 4,45 \\
\cline { 3 - 4 } - ESP 240 & & no less than 5, 99 & 6,60 \\
\hline
\end{tabular}

The main advantages of using energy-saving panels: installation on any foundation, any internal and external decoration; construction of facilities without the use of load-lifting mechanisms; 100\% environmental friendliness; high bearing capacity of the structure; a significant reduction in heat consumption during operation (energy passivity); high heat transfer resistance; simplicity and speed of installation of structures in any climatic conditions and allowing the construction of facilities in cold regions of Russia; any architectural decisions; repeated assembly cycle; biostability (excludes the development of fungi, molds, rodents); hydrophobicity; universality and repeated use of components.

2.

The parameters of the bearing abilities of energy-saving panels are presented in Table

Table 2

Parameters of bearing abilities of energy-saving panels

\begin{tabular}{|l|c|c|c|c|}
\hline The thickness of the energy-saving panel, mm & 80 & 160 & 240 & 320 \\
\hline $\begin{array}{l}\text { Bearing capacity of energy-saving panels with insulation, } \\
\text { kg, not less than }\end{array}$ & 1700 & 3400 & 5100 & 6800 \\
\hline
\end{tabular}
Table 3.

The results of the tests of energy-saving panels for flammability are shown in the

The results of the tests of energy-saving panels for flammability

\begin{tabular}{|c|c|c|c|c|c|c|}
\hline \multirow[b]{2}{*}{ Sample } & \multicolumn{3}{|c|}{ Temperature increase, ${ }^{\circ} \mathrm{c}$} & \multicolumn{2}{|c|}{ Sample weight loss, $\Delta \mathrm{mH} \cdot \mathrm{m \kappa}$} & \multirow[b]{2}{*}{$\begin{array}{c}\text { Duration of } \\
\text { sustained } \\
\text { flame burning } \\
\text { of the sample } \\
\text { t, sec }\end{array}$} \\
\hline & $\begin{array}{c}\text { In the oven } \\
\Delta \text { T }^{-}= \\
\text {Тпн - Тпк }\end{array}$ & $\begin{array}{c}\text { On the } \\
\text { surface } \\
\Delta \text { Тпо = } \\
\text { Тпо - Тпок }\end{array}$ & $\begin{array}{l}\text { In the } \\
\text { center } \\
\Delta \text { Тп = } \\
\text { Тцон - } \\
\text { Тцок }\end{array}$ & g & $\%$ & \\
\hline $\begin{array}{c}\text { GSP WS } \\
86\end{array}$ & 2 & 3 & 0 & 0,45 & 0,3 & 0 \\
\hline GSP W 70 & 2 & 1 & 2 & 0,55 & 0,4 & 0 \\
\hline GSP W 19 & 2 & 3 & 3 & 0,51 & 0,35 & 0 \\
\hline $\mathrm{F} 1$ & 3 & 1 & 2 & 0,72 & 0,5 & 0 \\
\hline F9 & 2 & 1 & 2 & 0,68 & 0,49 & 0 \\
\hline $\begin{array}{c}\text { The } \\
\text { average } \\
\text { value of } \\
\text { the } \\
\text { indicator }\end{array}$ & $\underset{{ }^{\circ} \mathrm{c}}{\Delta \mathrm{T}_{\Pi}=2,2}$ & $\Delta$ Тпо $=1,8^{\circ} \mathrm{c}$ & $\begin{array}{c}\Delta \mathrm{T}_{\Pi}=1,8 \\
{ }^{\circ} \mathrm{c}\end{array}$ & \multicolumn{2}{|c|}{$\Delta \mathrm{m}=0,41 \%$} & $\mathrm{t}=0^{\mathrm{o}}$ \\
\hline
\end{tabular}


Energy-saving panels non-combustible material (NG). The class of fire hazard of materials KM0. It has high heat and sound insulation characteristics, resistance to loads and various types of exposure and durability. The materials of this group do not emit harmful substances, products of combustion and do not have a negative impact on the environment. During use, as well as during prolonged use of energy-saving panels, there are no changes in their structure that can affect the properties and increase the fire hazard and, as a result, the design using energy-saving panels is reliable and safe.

The use of energy-saving panels in the construction of capital structures can significantly reduce construction costs, without compromising quality indicators: thermal conductivity and load-bearing properties of the object.

An example of an energy-efficient individual residential building and the general development concept are presented in Figure 1.
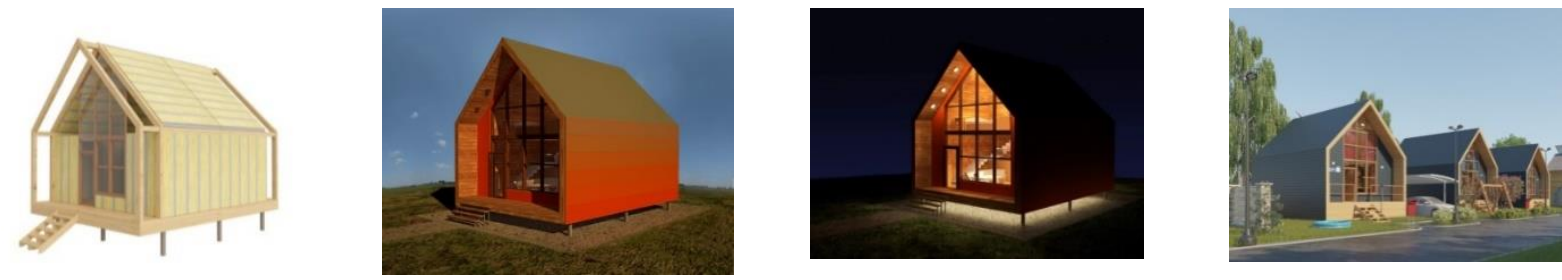

Figure 1. An example of an energy-efficient individual residential building and the general concept of development

The analysis of patent and scientific and technical literature did not reveal technical solutions with a similar set of essential features, which allows us to conclude that the criterion of "novelty" of the proposed utility model is met. Company in 2019 received a patent for an invention from the Federal Institute of Industrial Property, a subordinate organization of the Federal Service for Intellectual Property, and is currently seeking international protection for the invention under the existing patent cooperation agreement (PCT), which in the long term will provide a key advantage for the Russian Federation and directly Sverdlovsk region, in the field of individual energy-efficient construction.

The use of energy-saving panels as a constituent element of capital construction can significantly reduce the cost of capital construction of an economy-class housing and reduce direct and indirect costs (up to 60\%), without compromising the quality indicators: thermal conductivity and load-bearing properties of a capital object, which allows attributing objects to energy efficiency class A and what makes individual housing affordable for low-income and social groups

Currently, the claimed method of construction of an energy-efficient building is used for the construction of capital individual residential buildings of low floors, and starting in 2018. municipalities issue permits for the construction of individual residential buildings, the material of which is energy-saving panels (ESP), which indicates industrial applicability.

$$
* * *
$$

1. Directive 2010/75/EU of the European Parliament and of the Council of 24 November 2010 on industrial emissions (integrated pollution prevention and control) // Official Journal of the European Union, 17.12.2010, P. L.334/17-L334/119.

2. Directive 2002/91/EC of the European parliament and of the Council of 16 December 2002 on the energy performance of buildings.

3. Directive 2010/31/ EU of the European parliament and of the council of 19 May 2010 on the energy performance of buildings. 
4. EN 15217:2007. Energy performance of buildings - Methods for expressing energy performance and for energy certification of buildings. - CEN. - European Committee for Standardization. 2007.

5. The Federal Law "On Energy Saving and on Improving Energy Efficiency and on Amending Certain Legislative Acts of the Russian Federation” of 23.11.2009 № 261.

6. A Comparison of Energy Efficiency Programmes for Existing Homes in Eleven Countries: Australia, Canada, Denmark, France, Germany, Italy, Japan, The Netherlands, Norway, Sweden, The United States, The Regulatory Assistance Project, Department of Energy and Climate Change United Kingdom, February 2010.

7. New construction and major renovation. For Public Use and Display LEED 2009 for New Construction and USGBC Member Approved November 2008. 